\title{
A NEW LXX FRAGMENT CONTAINING JOB 7:3-4 AND 7:91
}

\author{
Lincoln H. Blumell \\ (lincoln_blumell@byu.edu)
}

\begin{abstract}
Summary
This article presents an edition of a papyrus fragment from LXX Job that is housed in the Hatcher Graduate Library at the University of Michigan. The fragment likely dates to the sixth century $A D$ and comes from a codex. On the recto the fragment contains Job 7:3-4 and on the verso Job 7:9.
\end{abstract}

P.Mich.inv. 1252_3 is a rectangular papyrus fragment that measures 7:5 $\times 11: 5 \mathrm{~cm}(\mathrm{H} \times \mathrm{W})$ and preserves LXX Job 7:3-4 on the recto and $7: 9$ on the verso. The fragment is stored in the Hatcher Graduate Library at the University of Michigan and while the piece comes from Egypt the exact provenance is unknown. ${ }^{2}$ The fragment belongs to the bottom part of a codex and preserves the last four lines of each page; from the bottom of the last line on the recto to the bottom edge of the papyrus there is a blank space of $5.2 \mathrm{~cm}$, and on the verso the blank space measures $5.5 \mathrm{~cm}$. The text is written with dark brown ink and the extant lines of text average anywhere from five to fourteen letters per line. While the fragment is riddled with lacunae and the text is effaced in some places, in other places the text is relatively clear. Identification

1 I would like to thank Brendan Haug, archivist of the Papyrus Collection at the University of Michigan, for permission to publish this papyrus as well as Nikos Litinas for bringing it to my attention. For editions of papyri cited in this article I have followed the abbreviations given in J.F. Oates et al., eds., Checklist of Editions of Greek and Latin Papyri, Ostraca and Tablets (5th ed.: BASP Suppl. 9; Atlanta: Scholars Press, 2001). The online version is available at http:// papyri.info/ docs/ checklist.

2 The catalogue record for the piece is rather sparse; it merely records that Flinders Petrie acquired it in December of 1922. The online record can be accessed via http:// quod.lib.umich.edu/a/apis/. 
of this fragment was initially made based on the extant text preserved on lines 3 and 4 of the recto. A search for this text on the Thesaurus Linguae Graecae revealed that LXX Job 7:4 was a potential match and upon further examination this was confirmed; this subsequently led to the identification of the rest of the text on the fragment. ${ }^{3}$

Palaeographically the hand of the text is practised and regular with fluid and rounded letter forms that are characteristic of Alexandrian majuscule: ${ }^{4}$ alpha is written with a single stroke and a loop at the top; $\mathrm{mu}$ is rounded and written with a single stroke; the tau has roundels at the end of the crossbar; and the rho has a serif at the bottom of the vertical stroke. The letterforms share a number of distinct palaeographic affinities with the following texts: P.Amh. I 192 (mid sixth century AD; Deuteronomy 32:3-10); P.Grenf. II 112 (c. AD 577; Festal Letter); P.Oxy. XV 1820 (sixth century AD; Odyssey 18). Therefore, a sixth-century date for the fragment appears most likely.

The layout of the text is regular and there are no ligatures. It is written stichometrically with each stichos forming a uniform left margin and intervening text between the next stichos is indented. Overall the stichometric layout conforms to the stichoi of Ziegler's critical edition of LXX Job. ${ }^{5}$ Between Job 7:4a, the last line on the recto, and Job 7:9a, the first extant line on the verso, there are four and a half intervening verses. The intervening verses are comprised of 318 letters (following Ziegler's edition) and based on an average of twelve letters per linethe average line length of the extant text on the recto and verso- one could infer that there are about twenty six or twenty seven intervening lines of text that must precede the extant text on the verso. While this conjecture must be held with caution, if it is accurate then the fragment likely belonged to a single-column codex instead of a two-column codex because the latter appears to presuppose an exceptionally broad codex with potentially very short columns of text. Sticking with the single-column hypothesis it would seem that a column could have

3 The Thesaurus Linguae Graecae is an electronic database of ancient Greek texts. The website for this database can be accessed online at: http://stephanus.tlg.uci.edu.

4 As described in G. Cavallo and H. Maehler, Greek Bookhands of the Early Byzantine Period A.D. 300-800 (London: Institute of Classical Studies, 1987), 5; cf. A. Porro, 'Manoscritti in maiuscola alessandrina di contenuto profane: Aspetti grafici, codicologici e filologici', Scrittura e civiltà 9.1 (1985) 171-90.

5 J. Ziegler, ed., Septuaginta: Vetus Testamentum Graecum Auctoritate Academiae Scientarum Gottingensis editum: Vol. XI, 4 Iob (Göttingen: Vanderhoeck \& Ruprecht, 1984) $240-42$. 
contained about thirty or thirty-one lines of text and measured 18 or 19 $\mathrm{cm}$ in height given that the extant lines on the fragment average about $0.6 \mathrm{~cm}$. Adding the bottom margin of about $5.5 \mathrm{~cm}$ and assuming a top margin of about $3.5 \mathrm{~cm},{ }^{6}$ the total height of the codex could have potentially been somewhere between 27 and $30 \mathrm{~cm}$ in height. With the current width of the papyrus at $12.5 \mathrm{~cm}$, the result is a rectangular shaped codex that belongs to Group 8 of E. Turner's typology where the breadth of the codex is approximately half of its height. ${ }^{7}$ In terms of the overall length of the manuscript to which this fragment belonged, and assuming that it only preserved the book of Job, working with an average of five verses per column it would require a codex of approximately 214 pages, ${ }^{8}$ but this calculation is admittedly quite speculative.

As there are at present fewer than ten published papyrus fragments of LXX Job this fragment represents a welcome addition. ${ }^{9}$ It is tempting to identity this fragment with four other fragments scattered

6 To arrive at the height of the top margin I have employed E. Turner's ratio for upper and lower margins where he notes that on average bottom margins are higher than upper margins by a ratio of approximately 3:2. See E. Turner, The Typology of the Early Codex (Philadelphia: University of Pennsylvania, 1977), 25.

7 Turner, The Typology of the Early Codex, 20-21. The width of the papyrus preserves the contours of the left and right margins of the papyrus, so while it may have been slightly wider than $12.5 \mathrm{~cm}$ the present measurement seems close to the original size of the page. Taking the measurements 27 to $30 \mathrm{~cm}(\mathrm{H})$ by $12.5 \mathrm{~cm}(\mathrm{~W})$, the closest parallel cited by Turner is P.Lond.Lit. 126 (Demosthenes) of the third century AD that measures 29.5 by $13 \mathrm{~cm}(\mathrm{H} \times \mathrm{W})$.

8 This would require about 13 quires.

9 Additionally, there is a reference to a parchment copy of Job in a list of Christian books from the fourth-century, as well as a quotation of Job 36:19 from a Christian letter of the late fourth or early fifth century from Oxyrhynchus. P.Oxy. XVIII

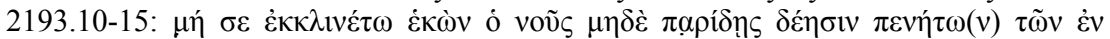
$\dot{\alpha} v \alpha ́ \gamma \kappa \eta ~ o ̈ v \tau \omega v$ ('let not thy mind of its own free will turn aside neither neglect the supplication of the poor, of them that are in distress'). Cf. LXX Job 36:19a: $\mu$ r $\sigma \varepsilon$

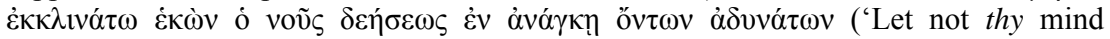
willingly turn thee aside from the petition of the feeble that are in distress'). For a detailed analysis of this passage see L.H. Blumell, Lettered Christians: Christians, Letters, and Late Antique Oxyrhynchus (Leiden / Boston: Brill, 2012), 212-13. Though P.Iand. II 14, a fourth-century Christian letter, has also been cited as containing a possible reference to Job 16:19, this seems very unlikely: 11. 3-4: $\pi \rho \grave{\rho} \mu[\dot{\varepsilon} v] \pi$ óv $\tau \omega \nu$

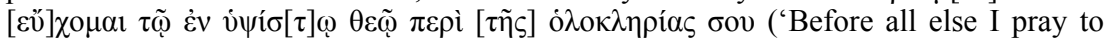

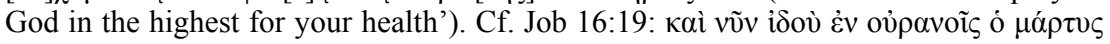

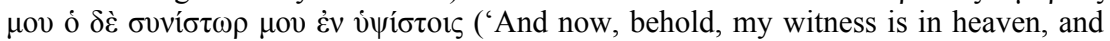
my advocate is on high'). On the potential allusion see M. Choat, 'Echo and Quotation of the New Testament in Papyrus Letters to the End of the Fourth Century', in T.J. Kraus and N. Tobias, eds., New Testament Manuscripts: Their Texts and Their World (Leiden / Boston: Brill, 2006) 291. 
throughout various collections, which belong to a sixth or seventhcentury codex of Job: ${ }^{10}$ the hands are similar and may both be described as Alexandrian majuscule; both are written with a dark brown ink; and both are written stichometrically. However, it appears on close examination that the present fragment is unlikely to belong to this codex. While the hands are similar there are some notable differences. For example, in the present fragment the epsilons are regularly written with a hasta that extends beyond the letter whereas the epsilons in the other codex fragments are consistently shorter and tend to have serifs. Also, it may be noted that in the present fragment the longest line consists of fourteen letters whereas in the other fragments, even if they are written stichometrically and can have short lines, lines are consistently comprised of twenty letters or more. In the present fragment lines of twenty or more letters would be very cramped or would require a much smaller script. It therefore appears that the present fragment does not belong to the same codex as these other fragments even if they share some similar features. ${ }^{11}$

\section{Fragments of LXX Job on Papyrus ${ }^{12}$}

\begin{tabular}{|c|c|c|c|c|}
\hline $\mathrm{LDAB}^{13}$ & Reference & Text & Date & Provenance \\
\hline 1. 3079 & P.Oxy. L 3522 & $42: 11-12$ & AD I & Oxyrhynchus \\
\hline 2. 3099 & BKT VIII 17 & $\begin{array}{l}33: 23-24 \\
34: 10-15\end{array}$ & AD III & Egypt \\
\hline 3. 3107 & $\begin{array}{l}\text { Am.Stud.Pap. XVI p. } \\
175\end{array}$ & $9: 2 ; 12-13$ & AD III & Egypt \\
\hline 4. 3163 & PSI X 1163 & $1: 19-2: 1 ; 2: 6$ & AD IV & Oxyrhynchus \\
\hline 5. 3267 & APF 20 (1970): 59 & $\begin{array}{l}31: 32-34 \\
31: 39-32: 1\end{array}$ & $\mathrm{AD} \mathrm{V} / \mathrm{VI}$ & Arsinoite \\
\hline 6. & P.Mich.inv. 1252_3 & 7:3-4; 7:9 & AD VI & Egypt \\
\hline \multirow[t]{3}{*}{ 7. 3305} & P.Ryl. I 2 & $\begin{array}{l}1: 15-21 ; \\
5: 24-6: 9\end{array}$ & AD VI/VII & Egypt \\
\hline & P.Lond.Lit. 210 & $14: 1-5,12-14$ & & \\
\hline & P.Amh. I 4 & $1: 21-22 ; 2: 3$ & & \\
\hline 6472 & P.Amh. II 201 descr. & $25: 4 ; 26: 5-6$ & & \\
\hline
\end{tabular}

10 See no. 7 in table below.

11 It may be noted that in these fragments that ovjpavó $\zeta$ is both written out in full and

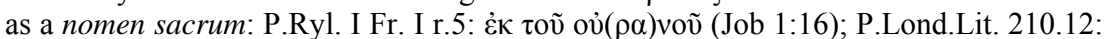
ó oủpavó (Job 14:14). Likewise, öv $\theta \rho \omega \pi$ o is apparently handled similarly: P.Amh. I

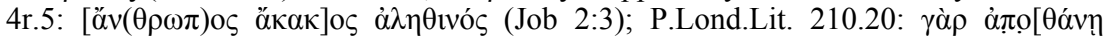
öv $\theta \rho \omega \pi \mathrm{s}$ (Job 14:14). 
The extant text of LXX Job preserved on the fragment follows the critical edition of Ziegler with the exception of what appears to be an orthographic variant on line 2 of the recto (see $n$. 2 below). Besides the orthographic variant there are a couple of other noteworthy features about this fragment. While the sixth-century date for the fragment, as well as the fact that it is written on a codex, should probably suggest a Christian context for this fragment, it is noteworthy that in two places where it could employ nomina sacra it does not. In line 3 on the verso, where Job 7:9a appears, oúpavoũ ('sky') is spelled out instead of employing the contraction ov̉( $\rho \alpha)$ vov and then a little later in the same verse in line $4 \not \alpha v \theta \rho \omega \pi \mathrm{s}$ ('a mortal') is spelled out instead of employing $\alpha \dot{\alpha} v(\theta \rho \omega \pi) o s$. However, it may be noted that both terms are treated rather irregularly in Christian literary papyri and sometimes are rendered as nomina sacra and at other times are spelled out in full. ${ }^{14}$

\section{Transcription}

\begin{tabular}{|c|c|c|c|}
\hline 7:3) & $\delta \varepsilon \delta[\mathrm{o}] \mu[\varepsilon v \alpha 1]$ & $(7: 9)$ & 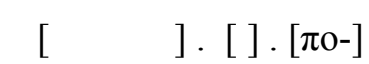 \\
\hline & $\begin{array}{r}{[\mu] \mathrm{or} \alpha} \\
{[\varepsilon \alpha] \vee \mathrm{\kappa o}}\end{array}$ & & $\begin{array}{l}\kappa \alpha[\theta \alpha \rho \theta] \varepsilon y, \alpha \pi \rho[v-] \\
\rho \alpha[v] \mathrm{ov}\end{array}$ \\
\hline & $\pi \mathrm{o} \tau \varepsilon \eta \mu \varepsilon \rho \alpha$ & 8 & $\varepsilon \alpha \vee \gamma[\alpha \rho] \alpha \vee \theta_{p}$ \\
\hline
\end{tabular}

\section{Notes}

$2[\mu]$ or $\alpha \in \underline{1}[\sigma 1] v$.

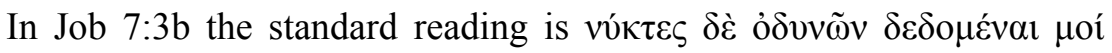
ciøuv ('and nights of pain have been appointed to me'). In the present

12 For a full list of LXX Job fragments including manuscript witnesses see D. Fraenkel, Verzeichnis der griechischen Handschriften des Alten testaments, Septuaginta Vetus Testamentum Graecum. Supplementum vol. I, 1 Die Überlieferung bis zum VIII Jahrhundert (Göttingen: Vandenhoeck \& Ruprecht, 2004) 481.

13 LDAB (= Leuven Database of Ancient Books) may be accessed at http://www. trismegistos.org/ldab/index.php.

14 A.H.R.E. Paap, Nomina Sacra in the Greek Papyri of the First Five Centuries: The Sources and Some Deductions (Leiden: Brill, 1959), where a survey of the different examples employed throughout the text reveals how these two words were rendered differently in various papyri. For the rendering of oủpavó specifically see pp. 86-87 and for $\ddot{\alpha} v \theta \rho \omega \pi \mathrm{s}$ see pp. 88-89. Cf. K. Aland, ed., Repertorium der Griechischen Christlichen Papyri: I, Biblische Papyri (Berlin: Walter de Gruyter, 1976), 420-28. On the use of nomina sacra in Christian documentary papyri see R.D. Bennett, A Case for the Relative Consistency of Nomina Sacra in Documentary Papyri (MA Macquarie University, 2012). 
fragment on line 2 of the recto, following $\mu$ oi ('to me') there is an alpha after which the text of the line is badly effaced. The alpha is curious because there is no known variant where $\mu$ oi is followed by a word beginning with alpha. ${ }^{15}$ One possible reconstruction is to read olọty assuming that $\varepsilon$ low was intended and that an $\varepsilon$ to $\alpha$ phonetic shift occurred. ${ }^{16}$ While this possibility is attractive because of its economy and relative straightforwardness, it does pose a minor problem for the reconstruction of the rest of the line. While an iota could be read following the alpha there is a gap of about a letter before what appears to be the sigma that cannot be accounted for. While it could be just an unusually large space between letters it is equally possible that another letter should be read before the sigma. The other possibility is to read açı unattested it does account for all of the spaces on the papyrus in this section of the line. In either case it therefore appears that the variant is not a textual one that changes the meaning of the text, but rather an orthographical variant that attests a different spelling. ${ }^{17}$

15 For variants for this verse see Ziegler, ed., Iob, 240 n. $3 b$.

16 On the phonetic shift of $\varepsilon$ to $\alpha$ see F.T. Gignac, A Grammar of the Greek Papyri of the Roman and Byzantine Periods: Volume I, Phonology (Milan: Istituto Editoriale Cisalpino-La Goliardica, 1976) 283-86.

17 If this manuscript was being copied via an oral reading, instead of directly from a textual exemplar, it may be wondered whether the pronunciation of the diphthong or immediately before sıбı contributed to the phonetic alternation. 


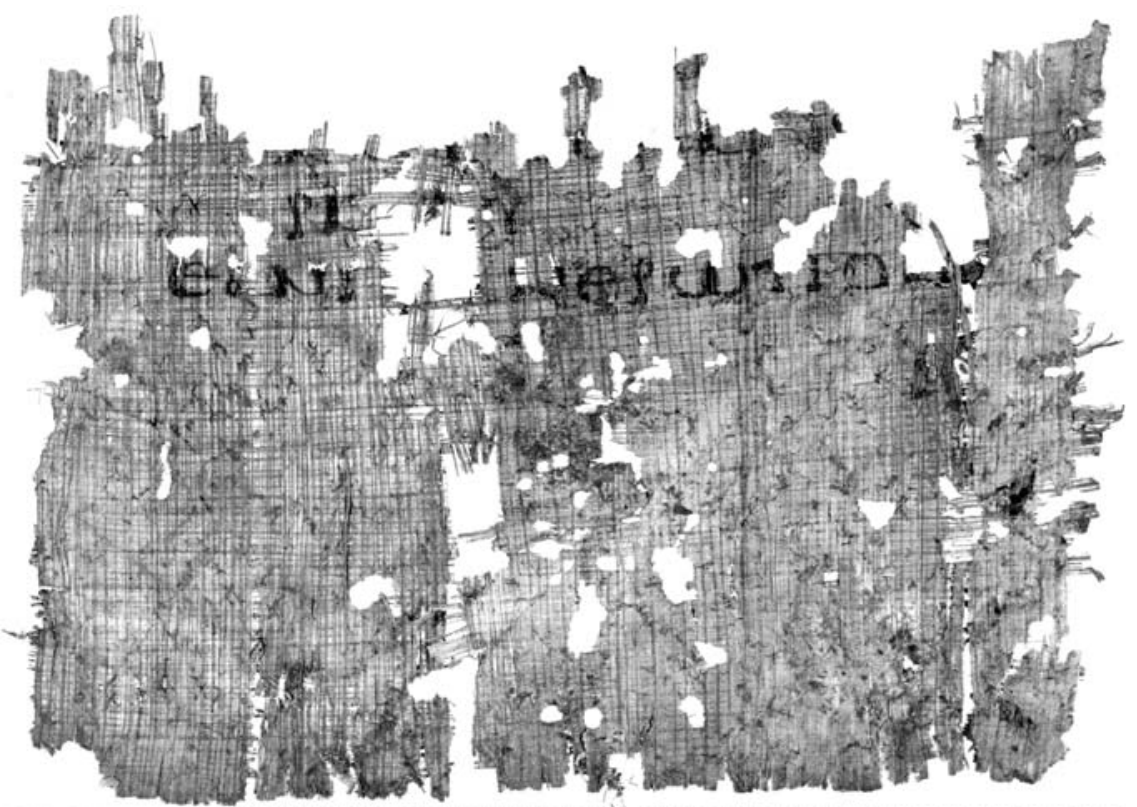

II||||||||||||||||||||||||||||||||||||||||||||||||||||||||||||||||||||||||||||||||||||||||||||||||||||||||||||||||||||||||||||||||||||||||

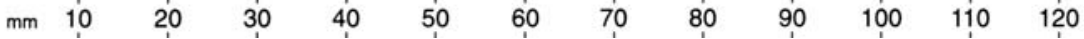

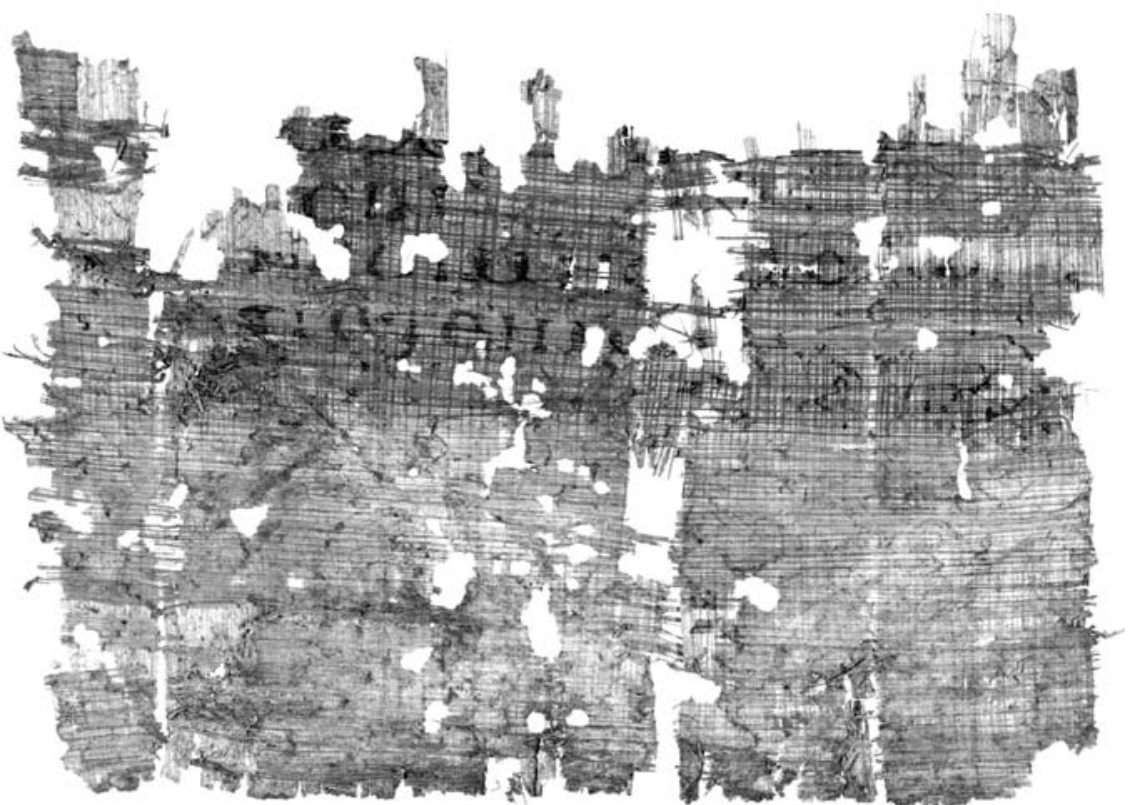

|| ||| |||||||||||||||||||||||||||||||||||||||||||||||||||||||||||||||||||||||||||||||||||||||||||||||||||||||||||||||||||||||||||||||||||||||

$\begin{array}{llllllllllll}\mathrm{mm} \quad 10 & 20 & 30 & 40 & 50 & 60 & 70 & 80 & 90 & 100 & 110 & 120\end{array}$ 